\title{
Ulakbilge
}

\section{THE ENDOGENEITY OF THE STEADY-STATE GROWTH RATE}

\section{Merter MERT}

Assoc. Prof. Dr., Ankara Hacı Bayram Veli University, Faculty of Economic and Administrative Sciences, Department of Economics, Ankara, merter.mert@hbv.edu.tr, https://orcid.org/0000-0003-0856-0267

Mert, Merter. "The Endogeneity of the Steady-State Growth Rate". ulakbilge, 59 (2021 Nisan): s. 504-516. doi: 10.7816/ulakbilge-09-59-02

\begin{abstract}
This study aims to estimate the steady-state growth rate or the natural growth rate and to determine whether the steady-state growth rate is endogenous to demand conditions or not. In order to achieve these aims, this study makes an econometric analysis using ordinary least squares method based on the data of Turkey covering the period 19692006. The present study estimates the natural growth rate and analyzes whether the natural growth rate is endogenous or not. But, different from the previous studies, the present study makes estimations in the conditions that capitaloutput ratio remains constant. According to the results of the study, the steady-state or natural growth rate is $5.71 \%$ in Turkey for the period 1969-2006. Moreover, the natural growth rate becomes $9.51 \%$ in the boom periods. This result shows that the steady-state or natural growth rate is endogenous to demand conditions in Turkey. Thus, the present study provides evidence for the Thirlwall's (1969) theory in a different manner.
\end{abstract}

Keywords: Natural growth rate, endogeneity, steady-state, capital-output ratio, economic history of Turkey 


\section{Introduction}

Steady-state growth occurs when capital-output ratio remains constant over time. How can we estimate the growth rate in the conditions that capital-output ratio does not change? Does the steady-state growth rate is endogenous? The main idea of the present study is to give answers these questions.

Why it is important to estimate the steady-state growth rate? In other words, what is the motivation behind that estimation? Following the studies such as Phelps (1961), the steady-state growth rate can also be named as the natural growth rate. The natural growth rate shows an economy's potential or the long-term or full employment growth rate. Therefore, it is an important indicator to estimate for an economy.

There are also other motivations behind the estimation of the steady-state growth rate. As an example, Dixit (1976) points out the following three explanations on the usefulness and necessity of the steady-state. i) Since all variables grow at a constant rate at steady-state conditions, agents can make true and trustworthy estimates. ii) Steady-state conditions are compatible with Kaldor's stylized facts, which are based on Kaldor (1961). iii) Steady-state conditions ensure a proper method of obtaining a notional tool to overcome the hard problems of dynamic economic analysis. Similarly, in another study, Atkinson and Jenkins (1984), the steadystate is entitled as an assumption and they show that this assumption supports identification of model coefficients. Thus, estimating a statistically significant steady-state growth rate makes it possible to analyze an economy's dynamic system in compatible with the theory.

Why it is important to determine that the steady-state growth rate or the natural growth rate is endogenous? The endogeneity of the natural growth rate has been discussed from various perspectives in the literature. Thirlwall (1969) firstly estimates the relationship which output growth rate depends on percentage level of unemployment. This is the reverse relationship of Okun (1962). Léon-Ledesma and Thirlwall (2002) make an econometric analysis about fifteen countries of Organization of Economic Cooperation for Development for the period 1960-1995. According to them the natural growth rate is endogenous; i.e. natural growth rate depends on actual growth rate. In other words, the potential growth of an economy depends on demand growth. Vogel (2009) examines whether the natural growth rate is endogenous for eleven countries of Latin America and she documents results which support Léon-Ledesma and Thirlwall (2002). Similar results are obtained by Libânio (2009) for ten countries of Latin America. Thus, Thirlwall (1969), Léon-Ledesma and Thirlwall (2002) and following studies explain the endogeneity of the natural growth rate regarding to the demand conditions. The natural growth rate will be endogenous if it rises in the boom periods. According to Léon-Ledesma and Thirlwall (2002), the endogeneity of the natural growth rate means that full employment ceiling is not constant; it can increase under certain conditions. If so, policies in order to provide stability should take into account this fact. In other words, if the full employment ceiling rises in the boom periods, economy does not have to tend to a stable path, automatically. In that case, an economy can tend to a stable path using a proper economic policy which takes into account demand conditions.

Thus, there are two aims of the present study: i) to estimate the steady-state growth rate; i.e. to estimate the natural growth rate, ii) to determine whether it is endogenous to demand conditions or not. In order to achieve these aims, the present study makes an econometric analysis using ordinary least squares (OLS) method based on the data of Turkey covering the period 1969-2006.

Apart from the previous studies, this study's main contribution is to estimate the natural growth rate and its endogeneity in the conditions that capital-output ratio does not change. According to the results of the study, the steady-state or natural growth rate is $5.71 \%$ in Turkey for the period 1969-2006. Moreover, the natural growth rate becomes $9.51 \%$ in the boom periods. This result shows that the steady-state or natural growth rate is endogenous to demand conditions in Turkey.

The paper is organized as follows: The next section explains the theory and literature. Following sections present the method and data, and results, respectively, which are followed by concluding remarks.

\section{Theory and literature}

Steady-state conditions show that all of the related variables such as capital, labour, consumption, and investment have a constant growth rate (see, for example; Hahn and Matthews, 1964; Burmeister and Dobell, 1970; Weiss, 1980). As it is emphasized in the introduction section, steady-state is a useful concept which is utilized in the dynamic analysis. Besides, steady-state growth is important since it gives the full employment or potential or long-term growth rate. A study on estimating the steady-state growth rate is Rao (2010), which is based on the neoclassical model. He estimates the steady-state growth rate for the East Asian tigers over the 
period 1970-2004. Rao (2010) augments the Solow (1956) using a model in which the level of technology is presumed as a function of learning by doing and openness to trade. Rao (2010) shows that externalities; i.e. learning by doing and openness to trade, provide an increase in the long run growth rates of Singapore, Malaysia, Thailand, Hong Kong, Korea and the Philippines. Rao (2010) finds evidence that if an exogenous growth model such as Solow (1956) is augmented properly, it can be used for designing a growth policy in order to increase long-term growth.

Different from the neoclassical perspective, the estimation of natural growth rate is relied on the study of Thirlwall (1969). Thirlwall (1969) is based on Arthur Okun (1962). Okun (1962) makes an analysis employing the equation (1).

$\Delta \% U=\rho_{0}-\sigma_{0} g$

where $\Delta \% U$ is the change in the percentage level of unemployment, $g$ is the growth rate of output. $\rho_{0}$ and $\sigma_{0}$ are coefficients to be estimated.

When the percentage level of unemployment does not change, the natural growth rate becomes $\rho_{0} / \sigma_{0}$. Thirlwall (1969) changes the equation 1 to estimate the natural growth rate, where the rate of growth of output is dependent variable.

$g=\rho_{1}-\sigma_{1} \Delta \% U$

$\rho_{1}$ and $\sigma_{1}$ are estimation parameters. Thus, if $\Delta \% U=0, \rho_{1}$ will be the natural growth rate. Note that $g$ is the actual and also the natural growth rate. Thus, the actual growth rate exceeds the natural growth rate in the boom periods. Moreover, the natural growth rate can rise in the boom periods, whether the natural growth rate is endog enous. To determine the increase in the natural growth rate, in other words, to determine the endogeneity, a dummy variable is added to the estimation equation. Dummy variable $\left(D_{0}\right)$ will be equal to 1 if actual growth rate exceeds the natural growth rate. Dummy variable $\left(D_{0}\right)$ will be equal to 0 if actual growth rate is below the natural growth rate.

$g=\rho_{2}-\sigma_{2} \Delta \% U+\alpha_{0} D_{0}$

If $\Delta \% U=0$ then $g=\rho_{2}+\alpha_{0}$, in the conditions where $\alpha_{0}$ is statistically significant. Moreover, if the sum of $\rho_{2}$ and $\alpha_{0}$ is greater than $\rho_{1}\left(\rho_{2}+\alpha_{0}>\rho_{1}\right)$, the natural growth rate will rise in the boom periods. This means that the natural growth rate, which is defined as the growth rate that holds the unemployment constant, increases in the boom periods. If so, this means that the natural growth rate is endogenous.

Following the estimation procedure explained above, the present study offers a similar estimation procedure for the steady-state growth rate.

Let us rewrite the equation 2 as equation 4 in order to estimate the steady-state growth rate.

$g\left(\frac{Y}{L}\right)=\phi_{0}+\beta_{0} g\left(\frac{K}{Y}\right)+u_{0}$

where $\phi_{0}$ and $\beta_{0}$ are parameters to be estimated. $u_{0}$ is the error-term. According to 4 , if $g(K / Y)=0, \phi_{0}$ will become the steady-state growth rate. Note that $g$ is the actual and also the steady-state growth rate. Hence, the actual rate of growth exceeds the steady-state rate of growth in the boom periods. Besides, the steady-state growth rate will rise during the boom periods, if the steady-state rate of growth is endogenous. To show the increase in the steady-state growth rate, in other words, to explain the endogeneity, a dummy variable is imposed to the estimation equation. Dummy variable $\left(D M_{0}\right)$ will be equal to 1 if actual growth rate exceeds the steady-state growth rate. Dummy variable $\left(D M_{0}\right)$ will be equal to 0 if actual growth rate falls behind the steady-state growth rate.

$g\left(\frac{Y}{L}\right)=\phi_{1}+\beta_{1} g\left(\frac{K}{Y}\right)+v_{0} D M_{0}+u_{1}$

If $g(K / Y)=0$ then $g=\phi_{1}+v_{0}$, at which $v_{0}$ is statistically significant. Moreover, if the sum of $\phi_{1}$ and $v_{0}$ is greater than $\phi_{0}\left(\phi_{1}+v_{0}>\phi_{0}\right)$, the steady-state rate of growth will rise in the boom periods. This means that the steady-state rate of growth, which is defined as the growth rate that holds the capital-output ratio constant, rises during the boom periods. If so, this means that the steady-state growth rate is endogenous to demand conditions. 
Besides, in the present study, a second dummy variable is used for a significant estimation. Dummy variable $\left(D M_{1}\right)$ equals to 1 for the years 1970, 1978, 1980, 1994, 1999, 2000 and 2001. These years are identified based on the important economic and social events in Turkey. 1970 is a year of crisis. 1978 is the year of the second moratorium in Turkey. 1980 is the year when a new structure started to emerge as a result of the 24 January decisions. 1994 is a year of crisis in Turkey. 1999 is the year of which Asian financial crisis effects has been seen in Turkey. The year 2000 is the year in which policies has been implemented within the scope of the Inflation Reduction Program, but ended with the crisis in November. The year 2001, on the other hand, is the year in which the February crisis has been experienced after the November 2000 crisis and the Transition to a Strong Economy Program has been implemented. Dummy variable $\left(D M_{l}\right)$ equals to 0 for the other years. Equation 6 represents one of the estimation equations.

$g\left(\frac{Y}{L}\right)=\phi_{2}+\beta_{2} g\left(\frac{K}{Y}\right)+v_{1} D M_{0}+v_{2} D M_{1}+u_{2}$

Finally, if equation 4 is rewritten including the dummy variable $\left(D M_{l}\right)$ equals to 1 for the years 1970,1978 , 1980, 1994, 1999, 2000 and 2001 and 0 for the other years, then the other estimation equation will be writt en as in equation 7:

$g\left(\frac{Y}{L}\right)=\phi_{3}+\beta_{3} g\left(\frac{K}{Y}\right)+v_{3} D M_{1}+u_{3}$

where $\phi_{3}, \beta_{3}$ and $v_{3}$ are estimation parameters. Note that equation 4 can also be written beginning from a production function. Production function is defined as follows:

$Y=K^{\alpha}(A L)^{\beta}$

where $K$ represents the capital, $L$ shows the labour, $Y$ represents the output and $A$ means the technology level. $\alpha$ and $\beta$ are parameters. All variables are function of time. Rewriting equation 8 as in 9:

$Y / L=A^{\beta} K^{\alpha} L^{\beta-1}$

Following Klenow and Rodriguez (1997), let us rearrange 9:

$Y / L=A^{\beta} L^{\beta-1} \frac{K^{\alpha}}{Y^{\alpha}} Y^{\alpha}$

$Y / L=A^{\beta} L^{\beta-1} \frac{K^{\alpha}}{Y^{\alpha}} Y^{\alpha} \frac{L^{\alpha}}{L^{\alpha}}$

$Y / L=A^{\beta} L^{\alpha+\beta-1} \frac{K^{\alpha}}{Y^{\alpha}} \frac{Y^{\alpha}}{L^{\alpha}}$

$\left(\frac{Y}{L}\right)^{1-\alpha}=A^{\beta} L^{\alpha+\beta-1}\left(\frac{K}{Y}\right)^{\alpha}$

$\frac{Y}{L}=A^{\frac{\beta}{1-\alpha}} L^{\frac{\alpha+\beta-1}{1-\alpha}}\left(\frac{K}{Y}\right)^{\frac{\alpha}{1-\alpha}}$

Rewriting equation 9 in terms of growth rate:

$\ln \left(\frac{Y}{L}\right)=\ln A+\frac{\alpha}{1-\alpha} \ln \left(\frac{K}{Y}\right)$

$g\left(\frac{Y}{L}\right)=g A+\frac{\alpha}{1-\alpha} g\left(\frac{K}{Y}\right)$

Note that $\alpha+\beta-1=0$ and $\beta=1-\alpha$ under constant returns to scale conditions in equation 14, equation 15 and equation 16. Thus, equation 4 can be written beginning from a production function as it is shown from equation 8 to equation 16 .

Let us explain the term natural growth rate. Roy Harrod defines the natural growth rate in his several works (see; Harrod, 1939; Harrod, 1948; Harrod, 1953). For example, according to Harrod (1953: 554) "the natural growth rate as being adapted to absorb any increase of population and any adjustments required by technological progress". Harrod (1939: 30) makes a definition as "the maximum growth rate allowed by the increase of population, accumulation of capital, technological improvement and the work/ leisure preference schedule, supposing that there is always full employment in some sense." Solow (1956: 67) also makes the following definition: Due to "exogenous population growth, the labour force increases at a constant relative rate 
$n$. In the absence of technological change population growth is Harrod's natural growth rate." Thus, it is widely admitted that the natural growth rate is the sum of the growth rate of labour and the growth rate of technological progress or labour productivity. There are several studies which use that definition (see, for example; Eltis, 1963; Meade and Hahn, 1965; Tobin, 1965; Steedman, 1972; Otani and Villanueva, 1990; Palley, 1996; Grabowski and Shields, 2000; De-Juan, 2007; Boianovsky and Hoover, 2009; Sasaki, 2013; Franke, 2018).

As it is explained before, according to another definition of the natural growth rate, it is the growth rate of output in the conditions at which the percentage level of unemployment does not change. Thirlwall (1969) makes this definition and it is the reverse relationship of Okun (1962). Empirical works of Léon-Ledesma and Thirlwall (2002), Vogel (2009), Libânio (2009), Dray and Thirlwall (2011) are depend on the natural growth rate definition of Thirlwall (1969).

The natural growth rate can also be defined as the growth rate in the conditions that capital-output ratio is constant. Matthews (1960) and Phelps (1961) explain the natural growth rate similarly. According to their analysis the natural growth rate is the growth rate of output where capital-output ratio is constant. In fact, under certain conditions, the growth rate of output which holds the capital-output ratio constant equals to the sum of growth rate of labour and labour productivity. Note that, in that case, the natural growth rate means the steadystate growth rate.

As a general result, the natural or steady-state growth rate is the growth rate at which capital-output ratio does not change. The present study takes up seriously that definition. In order to measure the natural or steadystate growth rate in compatible with that definition, this study uses a method similar to Thirlwall (1969) and Léon-Ledesma and Thirlwall (2002).

The endogeneity of the natural growth rate means that full employment ceiling depends on the demand conditions. In other words, it can rise in the boom periods. If so, there is not an automatic mechanism that moves the economy to the equilibrium, necessarily. The studies such as Léon-Ledesma and Thirlwall (2002), Vogel (2009), Libânio (2009) and Dray and Thirlwall (2011) which are explained in the introduction section, test the endogeneity of the natural growth rate and find evidence supporting to that hypothesis. There is one study for Turkey which analyzes this subject. Acikgoz and Mert (2010) estimate the natural growth rate following LéonLedesma and Thirlwall (2002) for Turkey over the period 1980-2008. According to them, Turkey's natural growth rate is $4.97 \%$ and it is endogenous to demand conditions.

\section{Method}

In order to examine the relationship between series, it is first determined whether the variables are stationary. The purpose of this test is to determine whether a possible relationship to be analyzed is statistically spurious or not. The stationarity test is performed by calculating the Augmented Dickey Fuller (ADF) test statistics (Dickey and Fuller, 1979).

After determining that variables are stationary at level, first, equation 7 is estimated by the ordinary least squares method. The estimation results of the equation 7 give the natural growth rate. Secondly, equation 6 is estimated by the ordinary least squares in order to determine the endogeneity of the steady-state or natural growth rate. Finally, diagnostic tests are implemented.

Note that one can make the following objection that the estimation should be made by using the equation 15 which shows the production function in natural logarithmic form. In the present study, the reason that not to be used the equation 15 for the estimation is the specific conditions of the study: If the equation 15 were used for the estimation equation, then, the dummy variable in order to determine the endogeneity would not be imposed to the equation. In other words, if we added a dummy variable to the equation 15 in order to determine the endogeneity, then it would be:

$\ln \left(\frac{Y}{L}\right)=\ln A+\frac{\alpha}{1-\alpha} \ln \left(\frac{K}{Y}\right)+D M_{0}$

where $D M_{0}$ would be equal to 1 if actual rate of growth exceeded the steady-state rate of growth and would be equal to 0 for the years that actual rate of growth fell behind the steady-state rate of growth. Then, we would say that when $\ln \left(\frac{K}{Y}\right)=0, \ln \left(\frac{Y}{L}\right)=\ln A+D M_{0}$. Since this statement does not give the growth rate, using equation 15 
for the estimation does not make sense.

The data source is Statistical Indicators of Turkish Statistical Institute (TUIK, 2014). The output data are calculated using the gross national product. The total number of employed people series is used for the labour force data. The installed capacity series in electric power plants are used for the capital stock series. There are important studies in the literature that discuss and suggest the use of electricity consumption as capacity utilization. (see, for example; Foss, 1963; Jorgenson and Griliches, 1967; Heathfield, 1972; Moody, 1974; Bosworth and Westaway, 1984; Ingram and Sloane, 1984; Bitzer and Gören, 2016; Elburz, Nijkamp and Pels, 2017; Elburz, Çubukçu and Nijkamp, 2018). In the current study, installed capacity series in electric power plants is used instead of capital stock. Finally, a second dummy variable $\left(D M_{l}\right)$ is used which is equal to 1 for the years 1970, 1978, 1980, 1994, 1999, 2000 and 2001 and 0 for the other years. These years are identified based on the important economic and social events in Turkey and briefly explained in the previous section.

\section{Results}

In this section, first, empirical results, then results about the endogeneity of the steady-state growth rate, are presented.

\section{Empirical results}

According to the results of the stationarity test in Table 1, the null hypothesis of "the series are nonstationary" is rejected at level. Thus, the series are stationary at level. Following the stationarity test, descriptive statistics are presented. According to the results of Jarque-Berra (JB) normality test, $g[Y / L]$ is not normally distributed, since the null hypothesis of "the series are normally distributed" is rejected. On the other hand, $g[K /$ $Y]$ is normally distributed, because the null hypothesis of "the series are normally distributed" is not rejected (see Table 2).

Table 1. Unit root test

\begin{tabular}{llll}
\hline Variables & $\begin{array}{l}\mathrm{ADF}^{\mathrm{a}} \\
t \text {-statistic } \\
\text { (none) }\end{array}$ & $\begin{array}{l}\mathrm{ADF}^{\mathrm{b}} \\
t \text { - statistic } \\
\text { (intercept) }\end{array}$ & $\begin{array}{l}\mathrm{ADF}^{\mathrm{c}} \\
t \text { - statistic } \\
\text { (intercept and } \\
\text { trend) }\end{array}$ \\
\hline Level & & & \\
\hline$g[Y / L]$ & $-5.6528(0)[0.0000]$ & $-7.3249(0)[0.0000]$ & $-7.2937(0)[0.0000]$ \\
\hline$g[K / Y]$ & $-4.6470(0)[0.0000]$ & $-6.0732(0)[0.0000]$ & $-6.3305(0)[0.0000]$ \\
\hline
\end{tabular}

Source: Author's own.

Notes: Numbers in parentheses indicate proper lag values. The values in square brackets are one-sided probability values calculated according to MacKinnon (1996). The proper length of lags are determined by Schwarz Information Criterion. The null hypothesis is "the series are non-stationary". ADF: Augmented Dickey-Fuller.

(a) Critical values are $-2.62,-1.95$ and -1.61 at $1 \%, 5 \%$ and $10 \%$ significance level, respectively.

(b) Critical values are $-3.58,-2.93$ and -2.60 at $1 \%, 5 \%$ and $10 \%$ significance level, respectively.

$\left({ }^{c}\right)$ Critical values are $-4.17,-3.51$ and -3.18 at $1 \%, 5 \%$ and $10 \%$ significance level, respectively.

Table 2. Descriptive Statistics

\begin{tabular}{ccccccccc}
\hline Variables & $\begin{array}{l}\text { Number of } \\
\text { Observations }\end{array}$ & Mean & $\begin{array}{l}\text { Standard } \\
\text { Deviation }\end{array}$ & Skewness & Kurtosis & Minimum & Maximum & Jarque-Berra-stat. \\
\hline$g[Y / L]$ & 38 & 0.0306 & 0.0571 & -0.7288 & 4.7111 & -0.1410 & 0.1684 & $\begin{array}{l}7.9996 \\
(0.0183)\end{array}$ \\
\hline$g[K / Y]$ & 38 & 0.0379 & 0.0670 & 0.1770 & 2.1054 & -0.0720 & 0.1747 & $\begin{array}{l}1.4657 \\
(0.4805)\end{array}$ \\
\hline
\end{tabular}

Source: Author's own.

Note: Numbers in parentheses are probability values. 
Then, equation 7 is estimated using OLS method. The estimation results are summarized in Table 3 . The estimated coefficients are statistically significant. The coefficient of determination is 0.51 . Durbin-Watson statistic indicates that there is no autocorrelation problem. F-statistic gives information about the overall significance of the model. According to the probability value of F-statistic, the model is overall significant.

Table 3. Estimation Results -I

\begin{tabular}{lllll}
\hline Dependent variable: $g[Y / L]$ & \multicolumn{3}{l}{} & \\
\hline & Coefficient & Standard Error & t-statistic & Prob. \\
\hline$g[K / Y]$ & -0.3280 & 0.1032 & -3.1782 & 0.0031 \\
\hline$D M_{1}$ & -0.0761 & 0.0176 & -4.3229 & 0.0001 \\
\hline Constant term & 0.0571 & 0.0080 & 7.1100 & 0.0000 \\
\hline Coefficient of determination & $\begin{array}{l}\text { Durbin-Watson statistic } \\
=0.5123\end{array}$ & $\begin{array}{c}\text { F-statistic }=18.3834 \\
\end{array}$ & F-statistic prob. $=0.0000$ & \\
\hline
\end{tabular}

Source: Author's own.

The estimated coefficient of $g[K / Y]$ is negative in Table 3. Note that, this coefficient does not mean the elasticity of per labour output with respect to capital/output ratio. As it is shown in the equation 16, the coefficient of $g[K / Y]$ is $\frac{\alpha}{1-\alpha}$. Then, it is estimated that $\frac{\alpha}{1-\alpha}=-0.33$. Thus, $\alpha=-0.49$. One can be opposed to this result, saying that the output elasticity of capital cannot be negative. On the other hand, the negative result of the output elasticity of capital is discussed in the literature. Felipe and McCombie (2002) make estimations on output growth using alternative econometric methods covering the period 1958-1991 based on the US aggregate manufacturing data provided from the NBER productivity database. They estimated output elasticity of capital as negative. It means that if capital stock grows 1\%, growth rate of output will be negative. According to Felipe and McCombie (2002), Hall's (1988) and Lucas's (1970) findings also support a negative value of output elasticity of capital. Tatom (1980) and Rajalakshmi (1985) are the other studies that report similar results. Felipe and McCombie (2002) bring an explanation to the negative values of output elasticity of capital. According to Felipe and McCombie (2002: 210), "it is because the rate of return, which varies procyclically, is omitted from, or wrongly approximated in, the regression". Moreover, in the literature it is shown that the rate of return can also be negative under certain conditions. According to Levhari and Sheshinski (1969), there can be negative rate of return under the conditions of high rates of embodied technical progress. Levhari and Sheshinski (1970) and Bardhan (1973) also support that finding. What does the negative rate of return of capital mean? If rate of return of capital is negative, then there will be no motivation to make a new investment. This is because the previous machine and equipment and other elements of the capital stock could not be used effectively. So, until the capital at the stocks is utilized effectively, there will be no need new investments. However, if technical progress results in a rise in effective labour, then, there will be need to make some new investments in order to embody the technical progress even if rate of return is negative. As an example, in the present study the elasticity of output with respect to capital is -0.49 . It means that, if capital increases $10 \%$, output will decrease approximately $-5 \%$. On the other hand, since it is presumed to be constant returns to scale, the elasticity of output with respect to effective labour becomes 1.49. Thus, when effective labour increases $10 \%$, output will increase approximately $15 \%$. This means that the percentage increase in the output due to the percentage increase in the effective labour compensates the percentage decrease in the output due to the percentage increase in the capital. As a consequence, producer can make investment even if rate of return of capital is negative since there is a necessity to invest in order to utilize from the technical progress. Moreover, if capital elasticity of output is negative this means that the share of factor income in the output will be negative. This cannot happen in a competitive economy. One explanation to that situation can be made depending on Felipe and McCombie (2002). According to them, the capital elasticity of output can differ from factor share of capital in output. There can be a second explanation on the negative factor shares that there can be other mechanisms that transfer income from labour to capital owners. The determination of that mechanism and the other debates above can be the subject of another study. Let us continue with the empirical results. 
Table 4. Descriptive statistics of residuals

\begin{tabular}{llllllll}
\hline $\begin{array}{l}\text { Number of } \\
\text { Observations }\end{array}$ & Mean & $\begin{array}{l}\text { Standard } \\
\text { Deviation }\end{array}$ & Skewness & Kurtosis & Minimum & Maximum & $J B$-stat. \\
\hline 38 & $-6.03 \mathrm{x}$ & 0.0399 & 0.3043 & 3.5627 & -0.0931 & 0.0959 & $\begin{array}{l}1.0879 \\
(0.5804)\end{array}$ \\
\hline
\end{tabular}

Source: Author's own.

Descriptive statistics of the residuals are documented in Table 4. According to the results of the JarqueBerra (JB) normality test in Table 4, the residuals are normally distributed, because the null hypothesis of "the series are normally distributed" is not rejected.

Wald test results are presented in Table 5. Wald test will provide information on the joint-significance of the estimated coefficients. According to Table 5, the null hypothesis that "the estimated coefficients together are equal to zero" is not accepted. This indicates that when the coefficients are evaluated together, a statistically significant estimate has been made. White test is implemented for the heteroscedasticity problem. Test results are presented in Table 6. According to Table 6, it is shown that there is no heteroscedasticity problem. Finally, Breusch-Godfrey LM test is used for the autocorrelation problem. Results are displayed in Table 7. According to the results, null hypothesis of no autocorrelation is accepted. So, there is no autocorrelation between series.

Table 5. Wald Test Results

\begin{tabular}{llll}
\hline$H_{0}: \phi_{3}=\beta_{3}=v_{3}=0$ & & & \\
\hline & Value & Degrees of freedom & Prob. \\
\hline F-statistic & 19.3111 & $(3,35)$ & 0.0000 \\
\hline Chi-square & 57.9333 & 3 & 0.0000 \\
\hline
\end{tabular}

Source: Author's own.

Note: $H_{0}$ is the null hypothesis.

Table 6. White Test Results

\begin{tabular}{cll}
\hline & Value & Prob. \\
\hline F-statistic & 1.1977 & 0.3302 \\
\hline
\end{tabular}

Source: Author's own.

Table 7. Breusch-Godfrey LM Test

$H_{0}:$ No serial correlation

\begin{tabular}{|c|c|c|c|}
\hline & Lag & Value & Prob. \\
\hline F-statistic & 2 & 0.3828 & 0.6849 \\
\hline
\end{tabular}

Source: Author's own.

Note: $H_{0}$ is the null hypothesis.

In order to analyze the endogeneity of the steady-state growth rate, equation 6 is predicted by applying OLS method. The estimation results are presented in Table 8 . The estimated coefficients are statistically significant. The coefficient of determination is 0.70. Durbin-Watson statistic shows that there is no autocorrelation problem. F-statistic gives information about the model's overall significance. Probability value of F-statistic shows that the model is overall significant.

Table 8. Estimation Results -II Dependent variable: $g[Y / L]$

$\begin{array}{llll}\text { Coefficient } & \text { Standard Error } & \text { t-statistic } & \text { Prob. }\end{array}$




\begin{tabular}{lllll}
\hline$g[K / Y]$ & -0.1766 & 0.0886 & -1.9922 & 0.0544 \\
\hline$D M_{l}$ & -0.0730 & 0.0141 & -5.1964 & 0.0000 \\
\hline$D M_{0}$ & 0.0601 & 0.0131 & 4.5893 & 0.0001 \\
\hline Constant term & 0.0350 & 0.0080 & 4.3629 & 0.0001 \\
\hline $\begin{array}{l}\text { Coefficient of determination } \\
=0.6989\end{array}$ & $\begin{array}{l}\text { Durbin-Watson } \\
=2.2838\end{array}$ & statistic & \multicolumn{2}{c}{$\begin{array}{l}\text { F-statistic }=26.3009 \\
\text { F-statistic prob. }=0.0000\end{array}$} \\
\hline
\end{tabular}

Source: Author's own.

Descriptive statistics of the residuals are shown in Table 9. According to the results of the Jarque-Berra (JB) normality test in Table 9, the residuals are normally distributed.

Table 9. Descriptive Statistics of Residuals-II

\begin{tabular}{llllllll}
\hline $\begin{array}{l}\text { Number of } \\
\text { Observations }\end{array}$ & Mean & $\begin{array}{l}\text { Standard } \\
\text { Deviation }\end{array}$ & Skewness & Kurtosis & Minimum & Maximum & Jarque-Berra-stat. \\
\hline 38 & $\begin{array}{c}-6.60 \mathrm{x} \\
10^{-18}\end{array}$ & 0.0314 & -0.3954 & 3.4233 & -0.0874 & 0.0628 & $\begin{array}{l}1.2689 \\
(0.5302)\end{array}$ \\
\hline
\end{tabular}

Source: Author's own.

Note: $J B$-stat is the Jarque-Berra normality statistic. Numbers in parentheses are probability values.

Table 10 gives Wald test results. According to Table 10, the null hypothesis that "the estimated coefficients together are equal to zero" is rejected. This result shows that when the coefficients are evaluated together, a statistically significant estimate has been made. After that, White test is employed for the heteroscedasticity problem. Results of White test are displayed in Table 11, indicating that there is no heteroscedasticity problem. Lastly, Breusch-Godfrey LM test is used for the autocorrelation problem. Findings are shown in Table 12. According to the results, null hypothesis of no autocorrelation is accepted. So, there is no autocorrelation between series.

Table 10. Wald test results-II

\begin{tabular}{llll}
\hline$H_{0}: \phi_{2}=\beta_{2}=v_{1}=v_{2}$ & & \\
\hline F-statistic & Value & Degrees of freedom & Prob. \\
\hline Chi-square & 28.0504 & $(4,34)$ & 0.0000 \\
\hline
\end{tabular}

Source: Author's own.

Note: $H_{0}$ is the null hypothesis.

Table 11. White test results-II

\begin{tabular}{cll}
\hline & Value & Prob. \\
\hline F-statistic & 1.5979 & 0.1743 \\
\hline
\end{tabular}

Source: Author's own.

Table 12. Breusch-Godfrey LM test -II

$H_{0}:$ No serial correlation

\begin{tabular}{clll}
\hline & Lag & Value & Prob. \\
\hline F-statistic & 2 & 0.6392 & 0.5343 \\
\hline
\end{tabular}

Source: Author's own.

Note: $H_{0}$ is the null hypothesis.

\section{Results on the natural growth rate and its endogeneity}


This section explains the estimated natural growth rate results. Let us rewrite equation 7 without $u_{3}$ and $D M_{1}$, as it is indicated in equation 17.

$g\left(\frac{Y}{L}\right)=\widehat{\phi_{3}}+\widehat{\beta_{3}} g\left(\frac{K}{Y}\right)$

where the hat symbol denotes the estimated coefficient.

The natural or steady-state growth rate is estimated when $g\left(\frac{K}{Y}\right)=0$. Then equation 7 becomes:

$g\left(\frac{Y}{L}\right)=\widehat{\phi_{3}}=0.0571$

As a result, it is estimated that the natural or steady-state rate of growth is equal to $5.71 \%$ in Turkey over the period 1969-2006.

Let us rewrite equation 6 without $u_{2}$ and $D M_{1}$, as it is indicated in equation 19.

$g\left(\frac{Y}{L}\right)=\widehat{\phi_{2}}+\widehat{\beta_{2}} g\left(\frac{K}{Y}\right)+\widehat{v_{1}} D M_{0}$

where the hat symbol denotes the estimated coefficient.

The natural or steady-state growth rate is estimated when $g\left(\frac{K}{Y}\right)=0$. Then equation 6 becomes:

$g\left(\frac{Y}{L}\right)=\widehat{\phi_{2}}+\widehat{v_{1}}=0.0601+0.0350$

Thus, the natural or steady-state growth rate becomes $9.51 \%$ in the boom periods in Turkey. This result clearly shows that, the natural or steady-state rate of growth is endogenous to the demand conditions in Turkey. Table 13 summarizes the estimation results of the natural growth rate.

Table 13. Estimated natural growth rate

I

(in the boom periods)

$\begin{array}{lll}\text { Growth rate }(\%) & 5.71 & 9.51\end{array}$

Source: Author's own.

\section{Conclusion}

An economy will grow at a steady-state path if capital-output ratio does not change. This study estimates the growth rate in the conditions at which capital-output ratio remains constant using ordinary least squares method based on the data of Turkey covering the period 1969-2006. Moreover, this study examines whether the steady-state growth rate is endogenous to demand conditions or not in Turkey for the relevant period.

Findings of the study show that the steady-state or natural growth rate is $5.71 \%$ in Turkey over the period 1969-2006. Besides, the natural growth rate rises from $5.71 \%$ to $9.51 \%$ in the boom periods. This evidence supports the endogeneity of the steady-state or natural growth rate to demand conditions in Turkey.

The empirical results indicate that policies in order to provide stability should take into account the endogeneity of the natural growth rate in Turkey. In other words, due to full employment ceiling rises in the boom periods, Turkish economy does not have to tend to a stable path, automatically. Thus, Turkish economy can tend to a stable path using a proper economic policy which takes into consideration demand conditions.

The present study's main contribution is, different from the previous studies, to estimate the natural growth rate and its endogeneity in the conditions that capital-output ratio remains constant, rather than in the conditions that the percentage level of unemployment does not change. Using this method, the present study finds evidence supporting the endogeneity of the steady-state or natural growth rate to demand conditions in Turkey.

The main constraint of the present study is the estimation results showing that output elasticity of capital is negative. This result is discussed in the literature. The present study only refers to the main studies that report output elasticity of capital is negative. The explanation is not made in detail. It is considered that there is no 
contradiction between significant and negative value of output elasticity of capital and significant and positive value of the steady-state growth rate. However, this issue should be discussed in further studies. Finally, one can analyze a group of country in order to estimate the steady-state or natural growth rate using panel data analysis or ARDL method. These are the recommendations of our study.

\section{References}

Acikgoz S., and M. Mert "The Endogeneity of the Natural Growth rate: An Application to Turkey". Panoeconomicus 57 (4), (2010): 447-469.

Atkinson, A., and S. Jenkins. "The Steady-State Assumption and the Estimation of Distributional and Related Models". The Journal of Human Resources 19 (3), (1984): 358-376.

Bardhan, P. "More on Putty-Clay". International Economic Review 14 (1), (1973): 211-222.

Bitzer, J., and E. Gören. "Measuring capital services by energy use, pp. an empirical comparative study". Applied Economics 48 (53), (2016): 5152-5167.

Boianovsky, M., and K.D. Hoover. "The neoclassical growth model and twentieth-century economics". History of Political Economy 41, (2009): 1-23.

Bosworth, D., and A. Westaway. "The Theory and Measurement of Capital Utilisation and Its Role in Modelling Investment”. Recherches Économiques De Louvain / Louvain Economic Review 50 (3/4), (1984): 303-329.

Burmeister, E., and A. R. Dobell. Mathematical Theories of Economic Growth, New York, 1971.

De-Juan, O. "The conventional versus the natural rate of interest, pp. implications for central bank autonomy". Journal of Post Keynesian Economics 29, (2007): 645-666.

Dickey, D., and W.A. Fuller. "Distribution of the Estimators for Autoregressive Time Series with a Unit Root". Journal of the American Statistical Association 74 (366), (1979): 427-431.

Dixit, A. K. The Theory of Equilibrium Growth. Oxford, Oxford University Press, 1976.

Dray, M., and A. P. Thirlwall, "The endogeneity of the natural growth rate for a selection of Asian countries". Journal of Post Keynesian Economics 33, (2011): 451-68.

Elburz, Z., Nijkamp, P., and E. Pels. "Public Infrastructure and Regional growth, pp. Evidence from Turkey". European Journal of Transport and Infrastructure Research 17, (4), (2017): 495-507.

Elburz, Z., Cubukcu, K. M., and P. Nijkamp. "The Mutual Relationship Between Regional Income and Deforestation, pp. A Study on Turkey". METU Journal of the Faculty of Architecture 35 (2), (2018): 77-87.

Eltis, W. A. "Investment, technical progress, and economic growth". Oxford Economic Papers, New Series 15, (1963): $32-52$.

Felipe, Jesus, and J. S. L. McCombie. "A Problem with Some Estimations and Interpretations of the Mark-up in Manufacturing Industry". International Review of Applied Economics 16 (2), (2002): 187-215.

Foss, M. "The Utilisation of Capital Equipment”. Survey of Current Business 43, (1963): 8-16.

Franke, R. "Harrod's long-range capital outlay as a stabilizer of Harrodian instability". Metroeconomica 70, (2018): 111.

Grabowski, R., and M. P. Shields. “A dynamic, Keynesian model of development”. Journal of Economic Development 25, (2000): 1-15.

Hahn, F., and R. Matthews. “The Theory of Economic Growth, pp. A Survey”. The Economic Journal 74 (296), (1964): 779-902.

Hall, R. E. "The relation between price and marginal cost in U.S. industry". Journal of Political Economy 96, (1988): 921-947.

Harrod, R. F. “An essay in dynamic theory”. The Economic Journal 49, (1939): 14-33.

Harrod, R. F. Towards a dynamic economics. London, Macmillan, 1948.

Harrod, R. F. "Full capacity vs. full employment growth, pp. Comment". The Quarterly Journal of Economics 67, (1953): 553-559. 
Heathfield, D. "The Measurement of Capital Usage Using Electricity Consumption Data". Journal of the Royal Statistical Society Series A 135, (1972): 208-220

Ingram, A. H. and P. J. Sloane. "The growth of shiftwork in the British food, drink and tobacco industries". Managerial and Decision Economics 5, (1984): 168-176.

Kaldor N. Capital Accumulation and Economic Growth. In, pp. Hague D.C. (eds) The Theory of Capital. International Economic Association Series. London, Palgrave Macmillan, 1961.

Jorgenson, D., and Z. Griliches. "The Explanation of Productivity Change". Review of Economic Studies 34, (1967): 249-283.

Klenow, P. J., and A. Rodríguez-Clare. "The neoclassical revival in growth economics, pp. Has it gone too far?". NBER Macroeconomics Annual 12, (1997): 73-102.

León-Ledesma, M., and A. P. Thirlwall. "The endogeneity of the natural growth rate". Cambridge Journal of Economics 26, (2002): 441-59.

Levharii, D., and E. Sheshinski. "The Relation between the Rate of Return and the Rate of Technical Progress". The Review of Economic Studies 36 (3), (1969): 363-379.

Levhari, D., and E. Sheshinski, "The Factor Price Frontier with Embodied Technical Progress". The American Economic Review 60 (5), (1970): 807-813.

Libânio, G. A. "Aggregate demand and the endogeneity of the natural growth rate, pp. Evidence from Latin American economies". Cambridge Journal of Economics 3, (2009): 967-984.

Lucas, R. E. "Capacity, overtime, and empirical production functions". The American Economic Review 60, (1970): $23-27$.

MacKinnon, J. G. "Numerical distribution functions for unit root and cointegration tests". Journal of Applied Econometrics 11, (1996): 601-618.

Meade J. E., and F. H. Hahn, "The rate of profit in a growing economy". The Economic Journal 75, (1965): 445-448.

Okun, A. "Potential GNP, pp. Its measurement and significance". Proceedings of the Business and Finance Statistics Section of the American Statistical Association, 7, (1962): 98-104.

Otani, I., and D.Villanueva. "Long-term growth in developing countries and its determinants, pp. An empirical analysis". World Development 18, (1990): 769-783.

Palley, T. I. "Aggregate demand in a reconstruction of growth theory, pp. The macro foundations of economic growth". Review of Political Economy 8, (1996): 23-36.

Rao, B. B. "Estimates of the steady state growth rates for selected Asian countries with an extended Solow model". Economic Modelling 27, (2010): 46-53.

Rajalakshmi, K. "Productivity in Electrical Machinery Industry in Leading States". Indian Economic Review 20 (2), (1985): 269-281.

Sasaki, H. "Cyclical growth in a Goodwin-Kalecki-Marx model". Journal of Economics 108, (2013): 145-171.

Solow. R. M. "A contribution to the theory of economic growth". Quarterly Journal of Economics 70, (1956): 65-94.

Steedman, I. "The state and the outcome of the Pasinetti process". The Economic Journal 82, (1972): 1387-1395.

Tatom, J. A. "The 'problem' of procyclical real wages and productivity". Journal of Political Economy 88, (1980): 385-394.

Thirlwall, A. P. "Okun's law and the natural growth rate". The Southern Economic Journal 36, (1969): 87-89.

Tobin, J. "Money and economic growth". Econometrica 33, (1965): 671-684.

TUIK. "Statistical Indicators 1923-2013". Turkish Statistical Institute, 2014.

Vogel, L. "The endogeneity of the natural growth rate, pp. An empirical study for Latin American countries". International Review of Applied Economics 23, (2009): 41-53.

Weiss, L. "The Effects of Money Supply on Economic Welfare in the Steady State". Econometrica 48 (3), (1980): 565 576. 


\title{
Ulakbilge
}

\section{DURAĞAN DURUM BÜYÜME ORANININ İÇSELLİĞİ}

\author{
Merter MERT
}

ÖZ

Bu çalışmanın amacı, durağan durum büyüme oranını, diğer bir deyişle doğal büyüme oranını tahmin etmek ve durağan durum büyüme hızının talep koşullarına bağlı olması anlamında içsel olup olmadığını saptamaktır. Bu amaçlara ulaşmak için Türkiye'nin 1969-2006 dönemini kapsayan verilerine dayalı olarak ve basit en küçük kareler yöntemi kullanılarak ekonometrik bir analiz yapılmıştır. Bu çalışmada konuya ilişkin önceki çalışmalardan farklı bir şekilde sermaye-çıktı oranının sabit kaldığı koşullarda tahmin yapılmışır. Çalışmanın sonuçlarına göre, Türkiye'de 1969-2006 döneminde durağan durum veya doğal büyüme oranı \% 5,71'dir. Ayrıca, canlanma dönemlerinde doğal büyüme oranı \% 9,51 olmuştur. Bu sonuç, Türkiye'deki durağan durum veya doğal büyüme hızının talep koşullarına bağlı olması anlamında içsel olduğunu göstermektedir. Bu nedenle, mevcut çalışma Thirlwall'un (1969) teorisine farklı bir açıdan kanıt sağlamıştır.

Anahtar kelimeler: Doğal büyüme oranı, içsellik, durağan durum, sermaye-hasıla oranı, Türkiye iktisat tarihi 